\title{
Profound Integration of Innovation and Entrepreneurship Education and Professional Education
}

\author{
Wang Qingjun \\ Economics and Management Institute \\ Shenyang Aerospace University \\ Shenyang City, China \\ 32582669@qq.com
}

\author{
Wu Jingtai \\ Economics and Management Institute \\ Shenyang Aerospace University \\ Shenyang City, China
}

\begin{abstract}
With the rapid development of China's economy, education in China has also changed. Especially, innovation education has already become the main direction for the development of China's current education as well as an important means connecting higher education and social development. The combination of innovation and entrepreneurship education with professional education is in line with the current requirement of China's social and economic development, and also provides new thoughts for the development of Chin's higher education. Starting from the connection between innovation and entrepreneurship education and professional education, this paper further elaborates on the necessity to combine these two and points out the best way to combine them.
\end{abstract}

Keywords-Innovation education; Innovation and entrepreneurship education; Professional education; Higher education

\section{INTRODUCTION}

For some time, cultivation of college students has already become an important purpose for each college and university. However, higher education in many colleges and universities is disconnected with the current social demands, thus many college graduates face unemployment upon their graduation. In recent years, with the emphasis on higher education, the Ministry of Education has carried out innovative education for college students, innovation and Entrepreneurship Program for college students, innovative ways of training college students. In some areas such as biology, medicine, electronics and other interdisciplinary, through the curriculum reform and personnel training mode, guide the university to establish a suitable way to run, will cross discipline as a breakthrough point to transform the results of various disciplines to provide platform for high-end talent, the professional education and innovation and entrepreneurship education is closely combined to enhance students' innovation practice ability, to provide help for their employment competitiveness, more favorable to provide some of the practice.

\section{RELATIONSHIP BETWEEN ENTREPRENEURSHIP \\ EDUCATION AND PROFESSIONAL EDUCATION}

Entrepreneurship education differs from other subjects in that it puts more emphasis on the process and practice while other subjects focuses on the learning of theoretical knowledge. Entrepreneurship Education in the actual process through the realization of its own education objectives, content, ways, and further enrich the entrepreneurial education. Through entrepreneurship education mode of comparative higher education in western countries, almost no identical entrepreneurship education mode, different countries, different model of college education has its uniqueness, which also resulted in there is no law to follow by the entrepreneurship education, which requires colleges and universities according to the uniqueness of their education to carry out the entrepreneurship education.

Segments of majors in higher education originated in the United States and European countries during the Big Industrial Age, and cultivation goals are determined with the division of majors to determine talents for the later industrial production. Division of majors is conducive to realizing goals like standardization and batch production, etc. However, with the development of scientific and technological progress and social and economic, the original training model has a certain discrepancy with the current needs of the community, and the current social and economic development needs creative thinking, it has a more distinct personality of the individual. This requires the University of professional education should be combined with each student's personality characteristics to develop training programs to encourage students in their own interests as the basis, to pursue a higher level of learning, into the knowledge of other disciplines, will be the discipline with other discipline combined with each other to meet the current needs of the community to cultivate innovative talents.

Education of basic knowledge and later professional education are two important parts constituting higher 
education in each country. Basic knowledge education focuses on cultivating students' personality: to teach them how to be a person and how to fulfill the obligations of citizens while professional education cultivates students' skills in a certain field or certain career skills, thus it is a means to teach students to make a living. Compared with basic education, entrepreneurship education is generally a collection of knowledge in a number of different disciplines, more professional than the basic education. The biggest difference between entrepreneurship education and basic knowledge education lies in the combination of the theoretical knowledge and practical practice of the University's professional education, and provides a suitable way to realize it. Taking the entrepreneurship education in Europe and America as an example, the entrepreneurship education curriculum is oriented to all the students, taking the pioneering education as the foundation to explore the cultural value of the core, to pursue higher levels of human activities. From the perspective of entrepreneurship education in western countries, the business education is of great significance, and provides a platform for students to understand their own value and pursue a higher level of core culture. It is seen that entrepreneurship education provides a platform for the integration between different disciplines of practice [1].

There are some problems to be clarified in terms of integrating entrepreneurship education and professional education: First, whether a relatively independent subject totally different from other subjects can be divided from entrepreneurship education. Second, in what way can entrepreneurship education be integrated with professional education? Third, how to obtain more support for entrepreneurship education to college students from the external environment? Western countries have good performance in these aspects, so we can learn a lot from their experience.

\section{VALUE ANALYSIS OF INTEGRATING INNOVATION AND}

ENTREPRENEURSHIP EDUCATION AND PROFESSIONAL

\section{EDUCATION}

\section{A. Integration of Innovation and Entrepreneurship Education and Professional Education is the Inevitable Choice of Reforming and Developing Higher Education}

Higher education in China develops from the period of planned economy since the founding of the country, so it has inherits some characteristics of the period of planned economy. These characteristics meet the objective development requirement of certain historical period, and play an invaluable role in promoting the development of China's economy and society. However, with the progress of society and the continued opening, the original philosophy of education in the era of planned economy, training objectives, training, teaching methods, and many other aspects cannot meet the needs of social development in the new era. This requires us to advance to the more advanced way to adapt to the times and the needs of social development. Innovation and entrepreneurship education adapts to demand of the times, embodies the characteristics of higher education in the new era. Teaching reform of higher education in the new era is to cultivate talents, training talents for the needs of social development, not only has a strong expertise and at the same time have a good ability to innovate. It can be seen that only combining innovation and entrepreneurship education and professional education is an inevitable step in the reform and development of higher education ${ }^{[1,2]}$.

\section{B. Integration of Innovation and Entrepreneurship}

Education and Professional Education is Due to the

\section{Demand of Promoting the Crossover and}

\section{Permeation of Various Subjects}

There is integration between the various disciplines in higher education, which will greatly promote discipline construction and development. Two innovation education itself should be made up of multiple disciplines, not of a single subject can bear. Innovation and entrepreneurship education combines various subjects like philosophy, psychology, engineering, science, economics, and other disciplines, all of which learn from each other and combine with each other. Such a convergence of innovation and entrepreneurship education includes all disciplines, for the progress and development of higher education to provide a new way of thinking.

C. Integration of Innovation and Entrepreneurship

Education and Professional Education is the

Objective Requirement of the Knowledge Economy

Era

After the expansion of China's higher education, higher education is popularized. And it was pointed out in the 17th CPC National Congress that the policy of increasing employment should continue to be implemented while further promoting entrepreneurship to bring about more employment. In this context, innovation and entrepreneurship education is carried out in each college and university, which not only accords to the current development direction of higher education, but also focuses on the future. Talents are the most important resources in the 21st century because without absent talents, economic progress is just like a daydream. The 21 st century is an era of knowledge economy, the most obvious feature of which is innovation. Only the combination of talents and innovation can further promote the development of economy and the society. China should improve the ability of independent innovation and comprehensively promote innovation modes in order to catch up with the advanced world level in economy, science and technology. Higher education plays a very important role in this regard because it lead college students to comprehensively conduct innovation and entrepreneurship activities while shouldering the heavy task to cultivate talents for China [2].

\section{Integration of Innovation and Entrepreneurship}

\section{Education and Professional Education is Due to the}

\section{Urgent Need to Establish an Innovative Country}

Innovation plays a key role for a country, is the core to promote all-round economic and social progress of the country's most dynamic, not only the country's comprehensive national strength, and power for the 
country's future development. Building an innovative country is the primary goal of our country currently faces, and building an innovation-oriented country needs a large number of talents to do support, these people need to have a strong ability to innovate. The cultivation of innovation ability, need to cooperate among universities, enterprises, social cooperative, one of the most critical is the two innovation education in higher education overall in the College. Thus, promoting innovation and entrepreneurship education in college education and professional integration play an important role in training a group of entrepreneurial capabilities and innovative personnel, but also promoting the construction of innovation-oriented country as well as economic development and progress of science and technology ${ }^{[3]}$.

\section{PATHS FOR INTEGRATING INNOVATION AND}

\section{ENTREPRENEURSHIP EDUCATION AND PROFESSIONAL}

\section{EDUCATION}

\section{A. Change the Concept of Education, and Strengthen}

the Combination of Innovation and

Entrepreneurship Educational Concept and

Professional Educational Concept

In order to closely combine innovation and entrepreneurship education with professional education, a better path for integration should be found, and the concept of professional education should be further integrated with the concept of innovation and entrepreneurship education. Only when the two concepts are integrated with each other, teaching coordination can be guaranteed, thus finally achieve the education goals. First, due to the restriction of various disciplines, the concept of professional education is generally simple, thus we need to change such educational concept and further realize the importance of innovation and entrepreneurship education. Generally speaking, innovation and entrepreneurship education targets at promoting students to start their own businesses and teaching them to suit this society and realize their own value in the society as well as how to better start their own businesses, give full play to their talents and in which way can their own businesses be accepted by the society. Professional education is the inevitable product of subject and career division, thus it is a powerful and practical tool. The ultimate goal of professional education is to cultivate students with professional skills so as to better adapt to the society. Second, we need to view the relationship between innovation and entrepreneurship education and professional education dialectically and establish the teaching concept of integrating the two. Innovation and entrepreneurship education is by no means a new form separated from professional education, but the further perfection and development of professional education and the supplement of professional education. The combination of innovation and entrepreneurship education with professional education is conducive to cultivate college students' awareness of innovation and entrepreneurship so as to effectively cultivate talents for the society and the country ${ }^{[3,4]}$.

\section{B. Deepen Teaching Reform and Organically Integrating Innovation and Entrepreneurship Education and Professional Education}

\section{1) Include Innovation and Entrepreneurship Education in the Talent Training Program}

Currently, innovation and entrepreneurship education has not been included in the talent cultivation scheme of colleges and universities, and meanwhile, it exists as the extra curriculum education while not being included in formal education, resulting in that innovation and entrepreneurship education cannot be integrated with professional education or they cannot develop by relying on formal education. Thus, although most students are enthusiastic in start their own business, they do not have powerful practical ability.

Currently, as a new course, innovation and entrepreneurship education is still at the initial stage with relatively week status and foundation. Therefore, in order to make innovation and entrepreneurship education develop better, they must be included in the talent cultivation scheme and integrate talents with innovative spirit, entrepreneurship skills and awareness of innovation into the entire talent cultivation scheme and implementation so as to make innovation and entrepreneurship education truly become important part and key mode of current talent cultivation in colleges and universities [4].

\section{2) Combination of Curriculum System and Teaching}

\section{Contents}

In order to well integrate innovation and entrepreneurship and professional education, the purpose must be transferred to improving students' ability and quality. Therefore, practices of curriculum system and teaching contents must be implemented specifically from the following two aspects:

Firstly, for the permeation of innovation and entrepreneurship education in professional education, crossover and integration of them should be strengthened and corresponding comprehensive curriculum system must be established according to the knowledge structure needed. This can not only expand the application scope of professional education, but also improve and optimize teaching contents.

Second, from the perspective of teachers, the previous teaching method should be changed and spirit of innovation and entrepreneurship education should be integrated into teaching with flexible forms of teaching to inspire and cultivate students the ability to find problems, and then solve them. Course contents should also be expanded accordingly and set some interdisciplinary and comprehensive subjects to expand students' horizons and improve their ability. In addition, special innovation and entrepreneurship courses and seminars can also be used to cultivate students' corresponding management and operation ability. Meanwhile, replace the career guidance curriculum that are only taught to seniors with the innovation and entrepreneurship courses that are taught throughout the entire four years of college to improve students' ability, and cultivate their quality together with 
teaching entrepreneurship knowledge, skills and professional knowledge $[4,5]$.

3) Strengthening the Construction of Teaching Staff, Cultivating and Integrating High-quality Teaching Team

Special training of innovation and entrepreneurship teaching team plays a vital role in implementing innovation and entrepreneurship education, and can effectively promote the deep integration of innovation and entrepreneurship education and professional education. However, at present, most colleges and universities in China still lack professional teaching team, so in order to cultivate dedicated innovation and entrepreneurship teaching team, schools should provide teachers with more academic exchanges and researches in the field of innovation and entrepreneurship education and send some excellent teachers to overseas schools with excellent innovation and entrepreneurship educational mode. However, Chinese teachers lack practical ability the most in innovation and entrepreneurship education, which is also a practical problem that cannot be ignored. Therefore, schools can hire some entrepreneurs and business starters to guide students and teach their experience and successful cases in innovation and entrepreneurship education to students and teachers, and establish specialized database about professions and entrepreneurial cases. In addition, schools can also arrange some teachers to be trained in some businesses in order to enhance their practical experience.

\section{Integration and Promotion of Professional Teaching}

Practice and Innovation and Entrepreneurship

\section{Teaching Practice}

In order to highlight the usefulness of innovation and entrepreneurship education, cultivation of practical ability in innovation and entrepreneurship education should be strengthened, which can be realized in the several following aspects specially: One, schools carry out some feasible innovation and entrepreneurship projects to improve students' practical ability in innovation and entrepreneurship education. Two, various forms of extra curriculum entrepreneurial activities such as entrepreneurship contest and entrepreneurship forum should be conducted in order to enhance the communication and exchange within the student entrepreneurship group. Three, establish entrepreneurship base outside schools to provide platform and assistance to students. Four, local government should enhance support and favors for students to start their own businesses to provide good social environment and opportunities for practices of innovation and entrepreneurship education.

All in all, innovation and entrepreneurship education and professional education are an organic whole and both of them are important part of educational activities in colleges and universities with the purpose of cultivating high-quality talents with innovative spirit and entrepreneurship ability. It can be said that professional education is the basis, and innovation and entrepreneurship education is the practice while both of the two are closely connected and inseparable. Therefore, innovation and entrepreneurship education and professional education must be integrated together and supplement each other to improve students' innovative spirit and ability to start their own businesses based on establishing the solid foundation of professional knowledge. It is also the requirement for the constant progress of education, key measures of cultivating high level talents and the necessary way in China's educational reform to integrate the two further $[5,6]$.

\section{ACKNOWLEDGMENT}

The work is supported by Teaching reform project of Liaoning Province Education Department (UPRP20140202).

\section{REFERENCES}

[1] Huang Mao. Analysis of Integrating and Developing Innovation Education and Professional Education in Institution of Higher Education [J]. Education and Career, 2010 (5):74-76.

[2] Zeng Erlei. Research into the Developing Mode of Integrating Innovation Education in Professional Education and its Strategies [J]. Research into Institutions of Higher Education in China, 2010(12).

[3] He Yunfeng, etc. "5D" Student Evaluation Innovation based on the Concept of Evaluating Development, Teaching in Colleges and Universities in China, 2009(10).

[4] Litao. On Integration of Entrepreneurship Education and Professional Education in Institutions of Higher Education [J]. Monthly Journal of Scientific and Technologic Entrepreneurship, 2010(3).

[5] Lu Jianhong. Thoughts on Integrating Entrepreneurship Education and Professional Education in Higher Vocational Education [N] Guangming Daily, 2009-12-31 (12).

[6] Li zhenshan, Sun Zhenwu. Implementing Entrepreneurship Education is the Necessary Choice to Reform and Develop Higher Education $[\mathrm{J}]$. Journal of Kunming University of Science and Technology (social science edition), 2003(9):80-84. 